\title{
Uma expressão eclesial: Estudo da RCC Brasil à luz das atuais transformações espaciais
}

Orientador: Joel Portella Amado

Mestranda: Cátia Valeria Fernandes da Silva

Área de Concentração: Teologia Sistemático-Pastoral

Linha de Pesquisa: Religião e Modernidade

O presente trabalho teve por objetivo fazer uma reflexão sobre a RCCBrasil e as atuais transformações espaciais urbanas com a intenção de evidenciar as implicações para o meio eclesial católico. Toda a atuação da RCCBrasil no território brasileiro, desde o seu surgimento, está inserida nas principais cidades do país. Assim, é de extrema importância o destaque que esse trabalho dá as implicações do espaço urbano e suas decorrências para a composição do ambiente eclesial católico. Essas implicações permitem pensar sobre as possibilidades da ação evangelizadora em lugares marcados por novos usos, arranjos espaciais e transformações constantes. Esta dissertação vai retratar como a RCCBrasil foi estendendo suas atividades por todo o território brasileiro ao longo dos anos e organizando uma estrutura para dar suporte ao surgimento dos grupos de oração, eventos de formação e louvor. A pesquisa demonstra que o desenvolvimento da RCCBrasil foi rápido, e a diversidade regional não foi um obstáculo para o crescimento do número de membros, que são assessorados pelos diversos ministérios, pelo Escritório Nacional e pelas coordenações locais e regionais. Esse trabalho ressalta a ligação da RCCBrasil com a RCC em vários países e a importância da identidade do movimento carismático católico como uma forma de reavivamento religioso que se estendeu por vários continentes. $\mathrm{O}$ uso dos meios de comunicação, pela RCCBrasil serve como forma de divulgar suas atividades, identidade e a doutrina católica. A RCCBrasil coloca a disposição dos membros, principalmente no espaço virtual, informações sobre a Igreja Católica no Brasil e em Roma, destacando pronunciamentos dos bispos e do Papa.

Palavras-chave: RCC; espaço urbano; território. 